\title{
A STUDY OF URBAN WATER DEMAND IN SOUTH KALIMANTAN PROVINCE
}

\author{
Ulfa Fitriati, Novitasari, Muh. Afief Ma'ruf \\ Civil Engineering Department, Engineering Faculty \\ Lambung Mangkurat University, Banjarbaru, South Kalimantan, Indonesia \\ Email: ufitriati@unlam.ac.id
}

\begin{abstract}
This research projected the citizens and water demand in 13 regencies/cities in South Kalimantan Province from 2013 to the next 20 years. The results of the project were compared with the intake capacity to meet the demand in upcoming years. In projecting the population growth, five methods were used, namely aritmethic method, geometric method, linier regression method, exponential method and logarithmic method. The most appropriate method for projecting the population growth is the method which has the minimum value of standard deviation and the correlation value close to 1. Water demand was calculated based on some factors, such as the average water demand, the maximum level of water demand, and the water demand at peak hours. The existing intake capacity was then compared with the water demand projection. In almost all PDAM (Munipical Tap Water Company) observed, the capacity of water processing installation could not fullfill the water demand at the peak hours. The adequate intake capacity of PDAM was only in Balangan regency and Banjarmasin city.
\end{abstract}

Keywords: intake capacity, South Kalimantan Province, urban water demand

\section{INTRODUCTION}

Water resource plays an important role in supporting individual life, community, socioeconomic development of a region and environmental ecosystem. Various economic activities such as supplying raw water for household, agriculture, municipality, industry and energy always require not only the proper quantity and quality but aLo the reliable and sustainable service. The management of water resource manufacturing faces several complex issues in line with the population growth and the social and economic growth. In one part, the population growth increases the water demand for various purposes; on the other hand it leads to exploitation of water resources and its supports. The increasing water demand is in line with the population growth, social life standard improvement and economic development. Economic development in a region affects the population growth through the increase in vertility, chance of survival and mobility.

The high rate of economic development will be followed by the increase in urban water demand. Hence, the study of urban water demand in thirteen (13) regencies and cities in South Kalimantan province in the near future needs to be carried out.

The purposes of this study were to find out the percentage of the existing population growth based on the data of population for 5 years in order to predict the number of citizens for the next 5, 10, 15 and 20 years, to calculate the recent water demand until the next 20 years with an interval of 5 years, and to compare the intake capacity with the amount of water consumption in PDAM until the next 20 years.

\section{METHODS}

The percentage of population growth is needed to determine the average rate of population growth each year. The percentage of population growth can be calculated using the formula:

$$
r=\frac{\sum((\mathrm{P} 2-\mathrm{P} 1) / \mathrm{P} 1)}{(\mathrm{T} 2-\mathrm{T} 1)} \times 100 \%
$$

Explanation:

$r \quad=$ percentage of population growth

$P_{1} \quad=$ number of first-year population

(known)

$P_{2} \quad=$ number of last-year population

(known) 
$\begin{array}{ll}T_{1} & =\text { first year (known) } \\ T_{2} & =\text { last year (known) }\end{array}$

The projection of population in the future is very important in calculating the amount of drinking water demand in the future. This projection is based on the rate of urban development trend, direction of land use and availability of land to accommodate population growth.

Regarding to the rate of population growth in the past, statistical method is the most approriate method to estimate the number of citizens in the future. There are several methods that can be used to analyze the population growth in the future, namely arithmetic, geometric, linear regression, exponential and logarithmic methods.

To establish which method to be used, the determination of the lowest correlation value $\left(r^{2}\right)$ and standard deviation (STD) are needed.

$$
\mathrm{r}^{2}=\frac{\mathrm{n} \sum(\mathrm{P} . \mathrm{Pn})-\left(\sum \mathrm{P}\right)\left(\sum \mathrm{Pn}\right)}{\sqrt{\left(\mathrm{n} \sum(\mathrm{P})^{2}-\left(\sum \mathrm{P}\right)^{2}\right)\left(\mathrm{n} \sum(\mathrm{Pn})^{2}-\left(\sum \mathrm{Pn}\right)^{2}\right)}}
$$

$\mathbf{S T D}=\sqrt{\frac{\sum\left(\mathbf{P}_{\mathbf{n}}-\overline{\mathbf{P}}_{\mathbf{n}}\right)^{2}}{\mathbf{n}-\mathbf{1}}}$

Factors influencing the projection of clean water demand are as follow.

1. The number of population growth every year.

2. Service standard.

3. Water demand for installation and operational needs.

4. Water loss factor.

For analyzing clean water demand, domestic and non domestic water demands need to be taken into account.

The standard of domestic water demand according to Directorate General of Cipta Karya, Department of Public Works (DPU) 1996, can be seen in Table 1. Non domestic water demand based on the planning criteria in DPU can bee seen in Table 2 to 4 . These tables display a standard that can be used to calculate urban water demand if the detailed data about city and its facilities can be provided.

Table 1. Criteria of clean water planning

\begin{tabular}{|c|c|c|c|c|c|}
\hline \multirow{3}{*}{ Data } & \multicolumn{5}{|c|}{ City Category According To Number Of Population } \\
\hline & $>1,000,000$ & $500,000-1,000,000$ & $100,000-500,000$ & $200,000-100,000$ & $<20,000$ \\
\hline & Metropolis & Big city & Middle Town & Little Town & Village \\
\hline Household unit (SR) & 190 & 170 & 130 & 100 & 80 \\
\hline $\begin{array}{l}\text { Consumption } \\
\text { (L/person/day) }\end{array}$ & & & & & \\
\hline Hidrant Unit(HU) & 30 & 30 & 30 & 30 & 30 \\
\hline Consumption & & & & & \\
\hline Non Domestic & $20-30$ & $20-31$ & $20-32$ & $20-33$ & $20-34$ \\
\hline Consumption & & & & & \\
\hline Unit(L/person/day) & & & & & \\
\hline Water Loss (\%) & $20-30$ & $20-30$ & $20-30$ & $20-30$ & $20-30$ \\
\hline Maximum Day Factor & 1.1 & 1.1 & 1.1 & 1.1 & 1.1 \\
\hline Peak Hour Factor & 1.5 & 1.5 & 1.5 & 1.5 & 1.5 \\
\hline $\begin{array}{l}\text { The number of citizens in } \\
\text { every SR (person) }\end{array}$ & 5 & 5 & 5 & 5 & 5 \\
\hline $\begin{array}{l}\text { The number of citizens in } \\
\text { every HU (person) }\end{array}$ & 100 & 100 & 100 & $100-200$ & 200 \\
\hline $\begin{array}{l}\text { The rest of water in } \\
\text { distribution provider } \\
\text { (meter) }\end{array}$ & 10 & 10 & 10 & 10 & 10 \\
\hline Operational Hours (hour) & 24 & 24 & 24 & 24 & 24 \\
\hline $\begin{array}{l}\text { The Volume of Resevoir } \\
(\%) \\
\text { (Max Day Demand) }\end{array}$ & $15-25$ & $15-25$ & $15-25$ & $15-25$ & $15-25$ \\
\hline SR : HU & $\begin{array}{l}50: 50 \\
\text { to } \\
80: 20\end{array}$ & $\begin{array}{l}50: 50 \\
\text { to } \\
80: 20\end{array}$ & $80: 20$ & $70: 30$ & $70: 30$ \\
\hline $\begin{array}{l}\text { The Coverage Service } \\
\text { Area }(\%)\end{array}$ & 90 & 90 & 90 & 90 & 70 \\
\hline
\end{tabular}

Source: Directorate General of Cipta Karya, Departement of Public Works (1996) 
Table 2. Non Domestic Urban Water Demand Type I, II, III, and IV

\begin{tabular}{ccc}
\hline Sector & Value & Unit \\
\hline School & 10 & L/student/day \\
Hospital & 200 & L/bed/day \\
Local gvt. Clinic & 2000 & L/day \\
Mosque & 3000 & L/day \\
Office & 10 & L/officer/day \\
Market & 12000 & L/hectare/day \\
Hotel & 150 & L/bed/day \\
Restaurant & 100 & L/seat/day \\
Military Base & 60 & L/man/day \\
Industrial Area & $0.2-0.8$ & L/sec/hectare \\
Tourism Area & $0.1-0.3$ & L/sec/hectare \\
\hline
\end{tabular}

Source: Directorate General of Cipta Karya, Departement of Public Works (1996)

Table 3. Non Domestic Urban Water Demand Type V (village)

\begin{tabular}{ccc}
\hline Sector & Value & Unit \\
\hline School & 5 & L/student/day \\
Hospital & 200 & L/bed/day \\
Local gvt. Clinic & 1200 & L/day \\
Mosque & 3000 & L/unit/day \\
Little Mosque & 2000 & L/unit/day \\
Hotel & 90 & L/day \\
Industrial Area & 10 & L/day \\
\hline
\end{tabular}

Source: Directorate General of Cipta Karya, Departement of Public Works (1996)

Table 4. Non Domestic Urban Water Demand Other's Type

\begin{tabular}{ccc}
\hline Sector & Value & Unit \\
\hline Airport & 10 & L/sec \\
Port & 50 & L/sec \\
Train Station-Bus Terminal & 10 & L/sec \\
Industrial Area & 0.75 & L/sec \\
\hline
\end{tabular}

Source: Directorate General of Cipta Karya, Departement of Public Works (1996)

\section{RESULTS AND DISCUSSION}

According to Wikipedia Indonesia and the data from BPS South Kalimantan Province about the calculation data of population in 13 regencies / cities, the following are the results of the projection of population in South Kalimantan Province every five years.

Table 5. Population Projection in South Kalimantan Province

\begin{tabular}{lccccc}
\hline \multirow{2}{*}{ Regency/City } & \multicolumn{4}{c}{ Population (person) } \\
\cline { 2 - 6 } & 2013 & 2018 & 2023 & 2028 & 2033 \\
\hline Balangan & 119,171 & 132,147 & 147,406 & 162,665 & 177,924 \\
Banjar & 533,739 & 563,399 & 588,310 & 627,756 & 662,641 \\
Barito Kuala & 289,995 & 309,789 & 330,888 & 353,425 & 377,496 \\
Hulu Sungai Selatan & 224,474 & 238,674 & 252,874 & 267,074 & 281,274 \\
Hulu Sungai Tengah & 155,113 & 270,658 & 287,448 & 304,238 & 321,028 \\
Hulu Sungai Utara & 219,210 & 237,395 & 255,580 & 273,765 & 291,950 \\
Kotabaru & 308,730 & 325,951 & 346,784 & 367,617 & 388,450 \\
Tabalong & 231,718 & 240,865 & 247,616 & 252,283 & 255,852 \\
Tanah Bumbu & 306,185 & 333,185 & 353,259 & 367,133 & 377,746 \\
Tanah Laut & 313,725 & 337,096 & 362,153 & 389,072 & 417,992 \\
Tapin & 176,468 & 185,281 & 191,248 & 195,372 & 198,527 \\
Banjarbaru & 219,758 & 249,279 & 282,767 & 320,752 & 363,841 \\
Banjarmasin & 656,778 & 676,542 & 707,896 & 740,703 & 775,030 \\
\hline
\end{tabular}


Ulfa Fitriati, Novitasari, Muh. Afief Ma'ruf: A Study Of Urban Water Demand In South Kalimantan

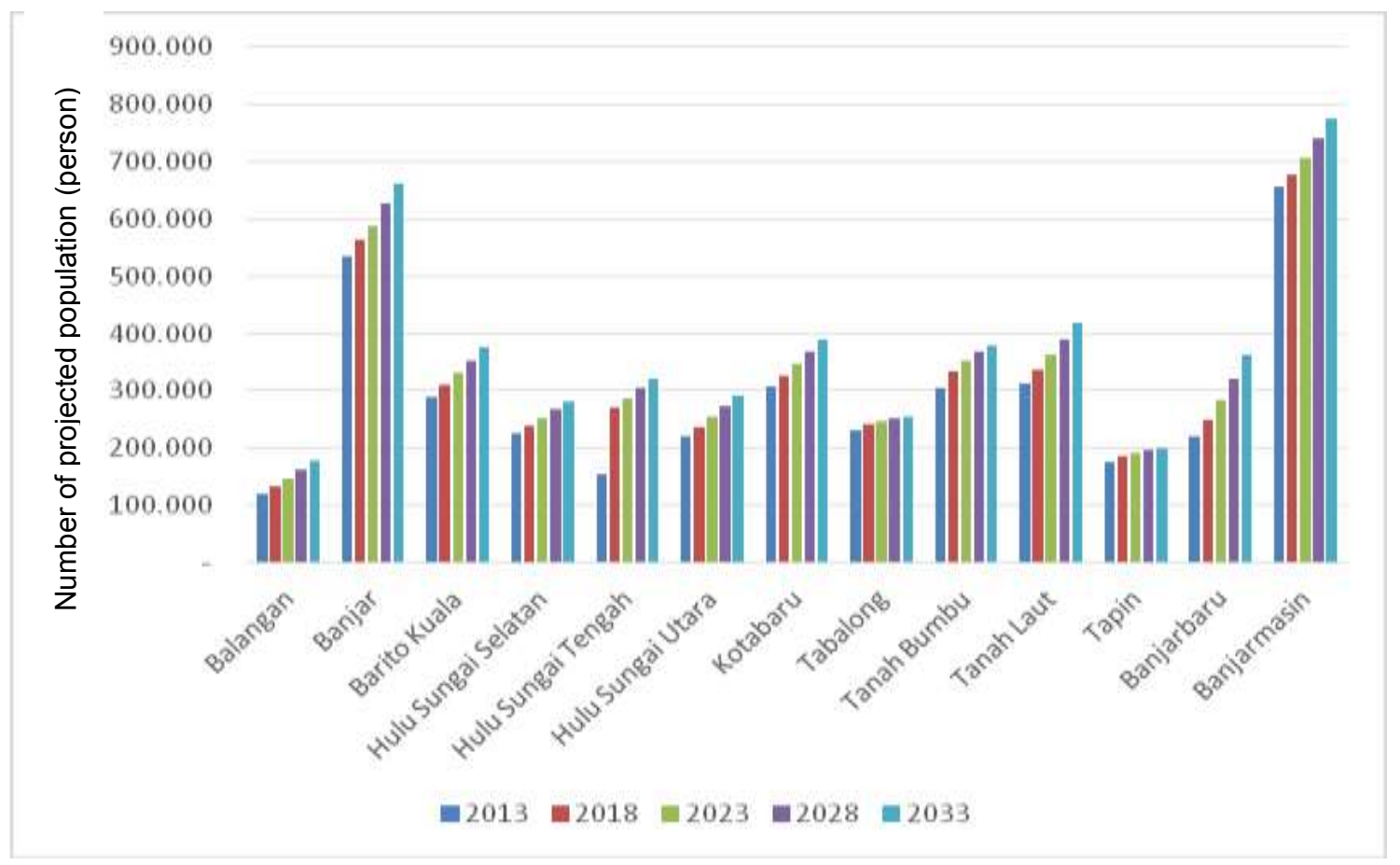

Figure 1. Projection of population in regencies/cities in South Kalimantan Province

In 2033, the lowest number of population is in Balangan regency with total 177,924 people and the highest number in Banjarmasin city by 775,030 people. The average number of population in South Kalimantan Province is 376,135 people.

Table 6. Domestic water demand in regencies/cities in South Kalimantan Province

\begin{tabular}{|c|c|c|c|c|c|}
\hline \multirow[t]{2}{*}{ Regency/City } & \multicolumn{5}{|c|}{ Domestic water demand (L/sec) } \\
\hline & 2013 & 2018 & 2023 & 2028 & 2033 \\
\hline Balangan & 118.7 & 134.6 & 159.5 & 186.4 & 203.9 \\
\hline Banjar & 92.6 & 173.6 & 277.8 & 421.3 & 674.1 \\
\hline Barito Kuala & 121.1 & 197.2 & 252.8 & 315.0 & 384.5 \\
\hline Hulu Sungai Selatan & 167.3 & 151.9 & 193.2 & 238.0 & 286.5 \\
\hline Hulu Sungai Tengah & 152.1 & 172.3 & 219.6 & 271.1 & 327.0 \\
\hline Hulu Sungai Utara & 121.0 & 159.0 & 212.0 & 270.0 & 335.0 \\
\hline Kotabaru & 242.1 & 356.2 & 464.8 & 585.0 & 719.5 \\
\hline Tabalong & 76.7 & 130.0 & 185.4 & 241.6 & 298.5 \\
\hline Tanah Bumbu & 279.1 & 313.9 & 341.8 & 364.6 & 384.7 \\
\hline Tanah Laut & 39.4 & 214.6 & 276.6 & 346.7 & 425.7 \\
\hline Tapin & 172.1 & 188.7 & 199.7 & 211.4 & 227.5 \\
\hline Banjarbaru & 88.2 & 182.3 & 264.9 & 502.7 & 730.0 \\
\hline Banjarmasin & $1,015.6$ & $1,111.9$ & $1,163.4$ & $1,217.4$ & $1,273.8$ \\
\hline
\end{tabular}




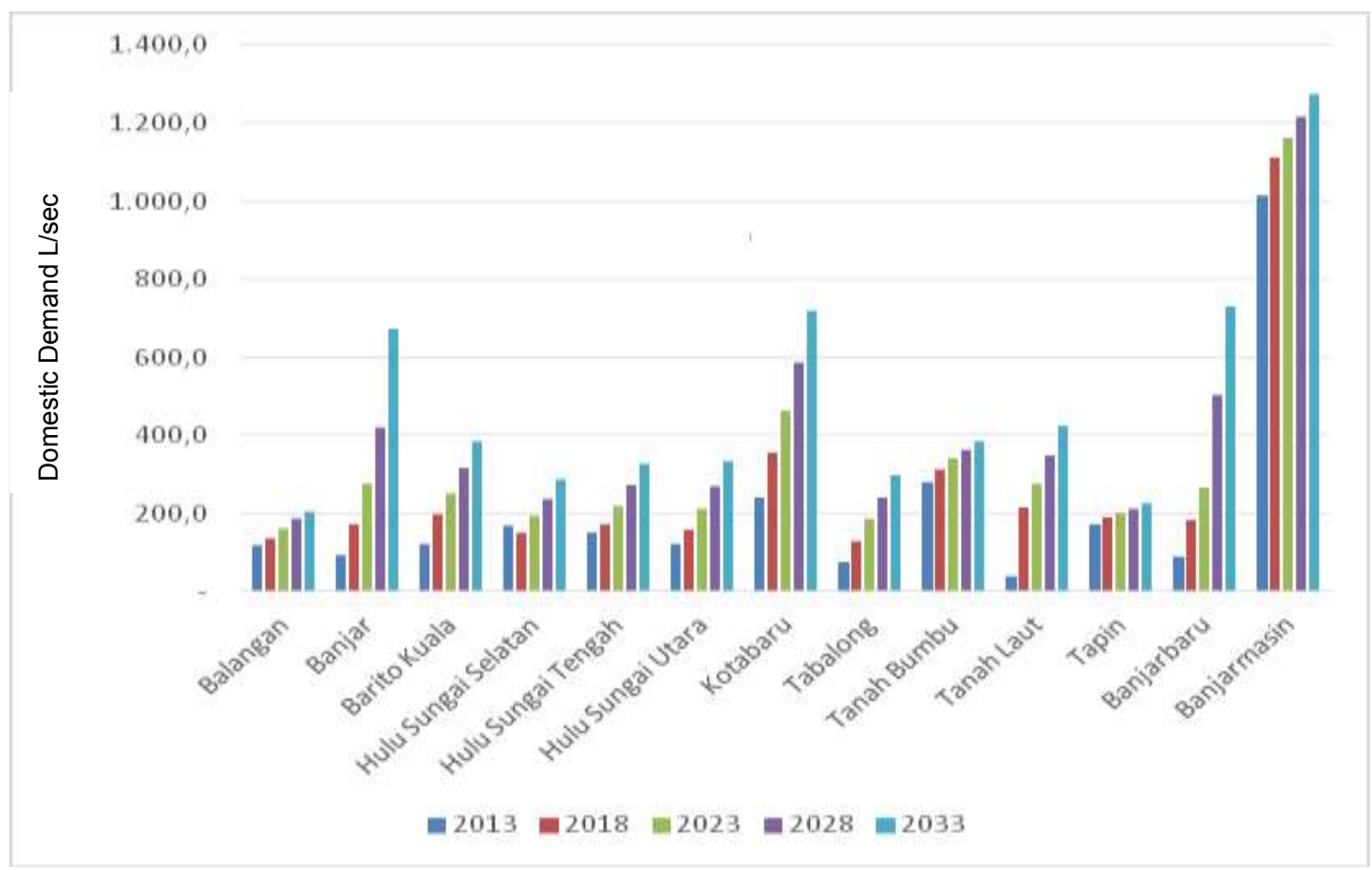

Figure 2. Domestic water demand in regencies/cities in South Kalimantan Province

In 2033, the lowest domestic water demand is in Balangan regency by $204 \mathrm{~L} / \mathrm{sec}$ and the highest is in Banjarmasin city by 1274
L/sec with the average rate of entire South Kalimantan Province population by $482 \mathrm{~L} / \mathrm{sec}$.

Table 7. Non domestic water demand in regencies/cities in South Kalimantan Province

\begin{tabular}{lccccc}
\hline \multirow{2}{*}{ Regency/City } & \multicolumn{5}{c}{ Non Domestic } \\
\cline { 2 - 5 } & 2013 & 2018 & 2023 & 2028 & 2033 \\
\hline Balangan & 17.6 & 19.9 & 23.6 & 27.6 & 30.1 \\
Banjar & 28.5 & 49.4 & 79.1 & 119.9 & 191.8 \\
Barito Kuala & 36.8 & 59.9 & 76.8 & 95.7 & 116.8 \\
Hulu Sungai Selatan & 35.2 & 31.9 & 40.6 & 50.0 & 60.2 \\
Hulu Sungai Tengah & 40.0 & 45.3 & 57.7 & 71.3 & 86.0 \\
Hulu Sungai Utara & 35.0 & 46.0 & 61.0 & 78.0 & 97.0 \\
Kotabaru & 35.0 & 58.6 & 85.5 & 115.2 & 148.0 \\
Tabalong & 46.5 & 112.4 & 146.5 & 181.0 & 112.4 \\
Tanah Bumbu & 32.7 & 36.8 & 40.1 & 42.7 & 45.1 \\
Tanah Laut & 39.4 & 85.8 & 138.3 & 198.2 & 266.1 \\
Tapin & 24.1 & 26.4 & 28.0 & 29.6 & 31.8 \\
Banjarbaru & 22.5 & 46.5 & 67.5 & 128.1 & 186.0 \\
Banjarmasin & 63.8 & 69.8 & 73.1 & 76.5 & 80.0 \\
\hline
\end{tabular}


Ulfa Fitriati, Novitasari, Muh. Afief Ma'ruf: A Study Of Urban Water Demand In South Kalimantan

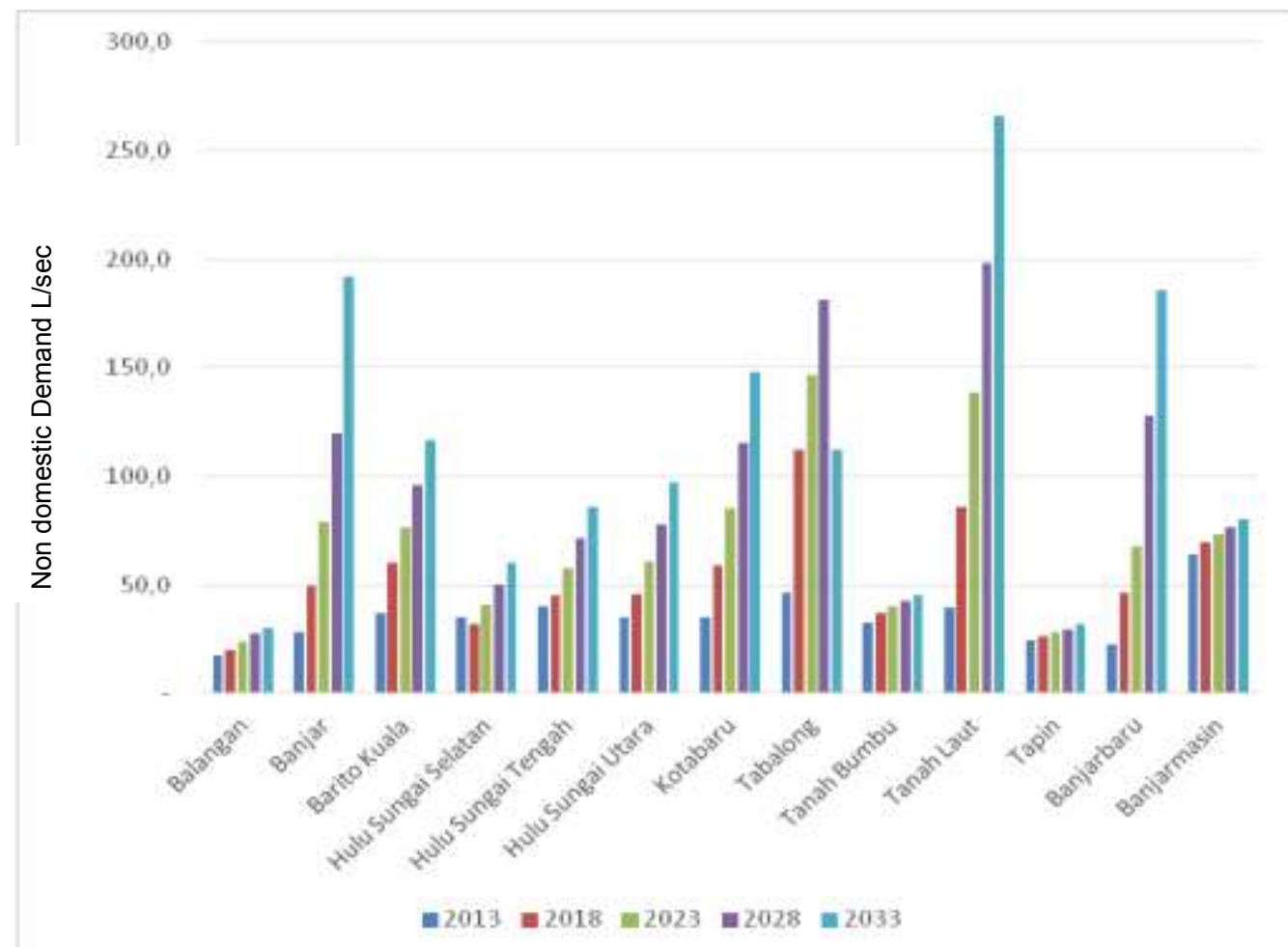

Figure 3. Non domestic water demand in regencies/cities in South Kalimantan Province

In 2033, the lowest non domestic water demand is in Balangan regency by $30 \mathrm{~L} / \mathrm{sec}$ and the highest in Tanah Laut regency by 266
$\mathrm{L} / \mathrm{sec}$ with the average rate of the entire South Kalimantan province population by $266 \mathrm{~L} / \mathrm{sec}$.

Table 8. Water demand at peak hours in regencies/cities in South Kalimantan Province

\begin{tabular}{lccccc}
\hline Regency/City & \multicolumn{5}{c}{ Water Demand at Peak Hours (L/sec) } \\
\cline { 2 - 6 } & 2013 & 2018 & 2023 & 2028 & 2033 \\
\hline Balangan & 244.7 & 278.1 & 329.6 & 385.1 & 421.2 \\
Banjar & 318.7 & 579.9 & 913.5 & $1,363.8$ & $2,164.8$ \\
Barito Kuala & 311.2 & 501.4 & 617.9 & 708.4 & 827.1 \\
Hulu Sungai Selatan & 399.9 & 355.0 & 440.8 & 530.1 & 627.7 \\
Hulu Sungai Tengah & 378.8 & 414.5 & 519.9 & 631.8 & 743.3 \\
Hulu Sungai Utara & 303.0 & 383.0 & 511.0 & 653.0 & 809.0 \\
Kotabaru & 234.7 & 392.5 & 571.5 & 766.4 & 978.6 \\
Tabalong & 221.7 & 536.1 & 698.6 & 863.0 & 536.1 \\
Tanah Bumbu & 546.3 & 614.4 & 669.0 & 713.6 & 753.0 \\
Tanah Laut & 149.4 & 324.5 & 514.6 & 725.2 & 957.9 \\
Tapin & 370.4 & 403.4 & 416.5 & 437.5 & 466.8 \\
Banjarbaru & 291.3 & 594.7 & 851.1 & $1,589.6$ & $2,290.0$ \\
Banjarmasin & $2,092.1$ & $2,251.2$ & $2,318.5$ & $2,387.1$ & $2,436.8$ \\
\hline
\end{tabular}


Ulfa Fitriati, Novitasari, Muh. Afief Ma'ruf: A Study Of Urban Water Demand In South Kalimantan

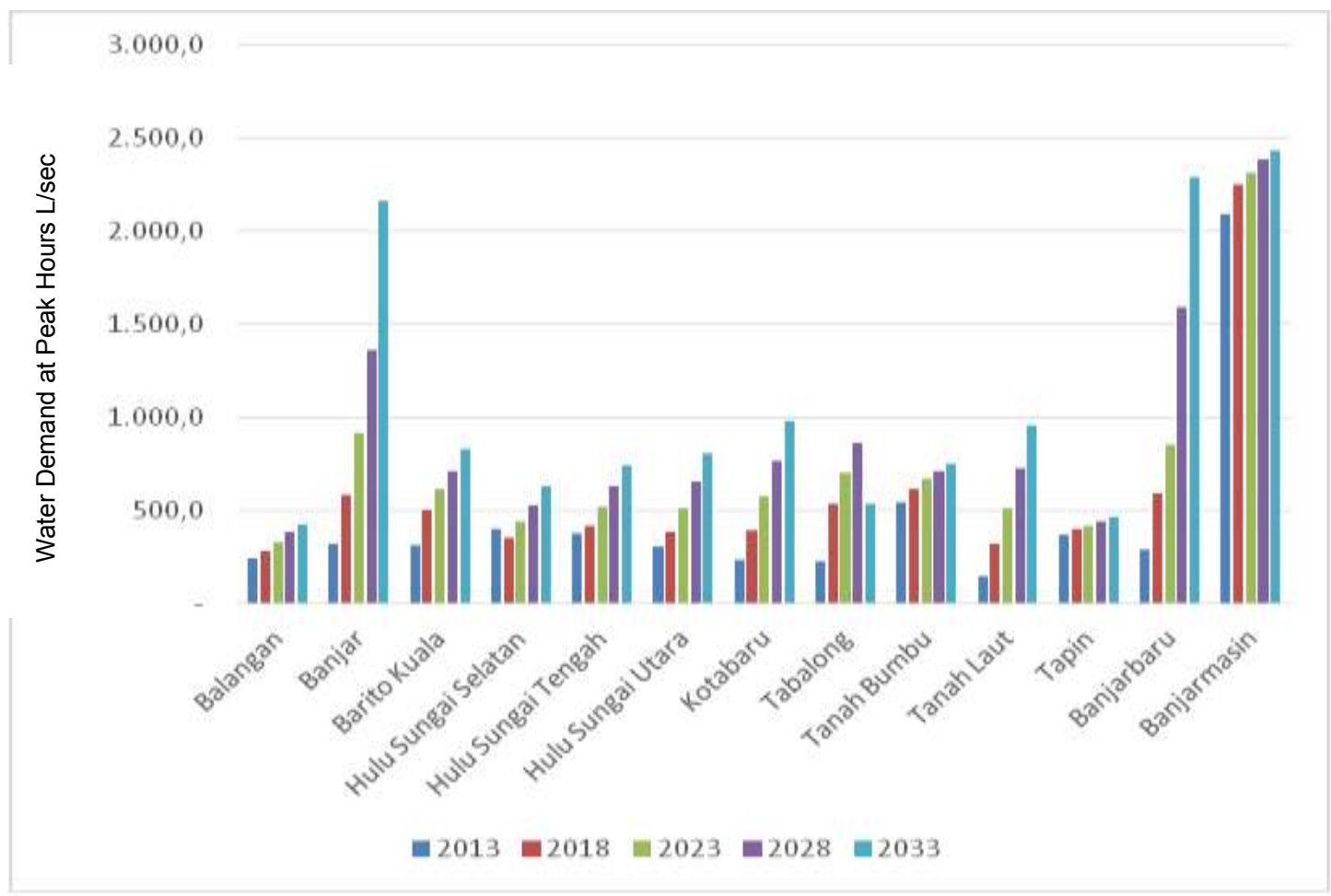

Figure 4. Water demand at peak hours in regencies/cities in South Kalimantan Province.

In 2033, the lowest water demand at with the average rate of the entire South peak hours is in Balangan by $421 \mathrm{~L} / \mathrm{sec}$ and the highest is in Banjarmasin by $2437 \mathrm{~L} / \mathrm{sec}$ Kalimantan population by $1078 \mathrm{~L} / \mathrm{sec}$.

Table 9. Intake capacity and water processing installation (IPA) capacity in regencies/cities of South Kalimantan Province.

\begin{tabular}{lcccc}
\hline Regency/City & $\begin{array}{c}\text { The Total of Intake } \\
\text { Capacity (L/sec) }\end{array}$ & $\begin{array}{c}\text { IPA Capacity } \\
(\text { L/sec })\end{array}$ & Intake & Year \\
\hline Balangan & 420 & 105 & 2033 & 2013 \\
Banjar & 360 & 360 & 2018 & 2018 \\
Barito Kuala & 310 & 310 & 2013 & 2013 \\
Hulu Sungai Selatan & 235 & 205 & 2013 & 2013 \\
Hulu Sungai Tengah & 169 & 169 & 2013 & 2013 \\
Hulu Sungai Utara & 298 & 298 & 2013 & 2013 \\
Kotabaru & 175 & 175 & 2013 & 2013 \\
Tabalong & 350 & 350 & 2018 & 2018 \\
Tanah Bumbu & 546 & 546 & 2013 & 2013 \\
Tanah Laut & 142 & 107 & 2013 & 2013 \\
Tapin & 452 & 328 & 2018 & 2013 \\
Banjarbaru & 360 & 360 & 2018 & 2018 \\
Banjarmasin & 3.500 & 2.100 & Secured & 2018 \\
\hline
\end{tabular}

Based on the data in Tables 8 and 9 , almost in all PDAM, the water processing installations could not meet the water demand at peak hours. Only Balangan regency and Banjarmasin city could afford it. Thus, the local government has to make new plans to increase the water processing installation (IPA) capacity and the machines in intake. Moreover, they have to think about new location of intake.

From the percentage in 2033, the regency or city which experiences the smallest population increase is Tabalong regency and 
the highest Hulu Sungai Tengah regency. However, the lowest increase in water demand at peak hours is in Banjarmasin city and the highest is in Banjarbaru city. This is understandable because the province capital has been moved from Banjarmasin to Banjarbaru since 2012.

\section{CONCLUSIONS}

From the results of data analysis in this research, it can be concluded that the lowest number of population is in Balangan regency $(177,924$ persons) and the highest is in Banjarmasin city $(775,030$ persons). However, the area with the lowest rate of population growth is Tabalong regency and the highest is Hulu Sungai Tengah regency. The lowest rate of water demand at peak hours is in Balangan regeny by $421 \mathrm{~L} / \mathrm{sec}$ and the highest in Banjarmasin city by $2437 \mathrm{~L} / \mathrm{sec}$ with the average number of population in South Kalimantan Province by 1,078 L/sec. However, the lowest rate of water demand at peak hours is in Banjarmasin and the highest in Banjarbaru. Almost in all PDAM, the capacity of water processing installation cannot meet water demand at peak hours. Only Balangan regency and Banjarmasin city have sufficient intake capacity.

There are some recommendations for providing clean water in Banjarmasin city. First, PDAM Banjarmasin must surpress the water loss until less than $20 \%$ in order to optimalize water distribution to citizens. Second, it needs to maintain the quality and sustainability of the environment near water sources and to prevent deforestation and river pollution. Next, it should maintain the efforts to optimalize the fulfillment of clean water demand such as by increasing both the existing capacity and intake production by adding the water extraction pump and increasing the volume of water processing shelter; increasing the number of intake points in rivers that have the potential for water resources for PDAM; optimalizing the water pump performance by replacing old pumps to maintain the stability of distributed water discharge; establishing a construction plan of artificial basin as the back-up water supply in case the existing water capacity is insufficient to meet water demand continually.

\section{REFERENCES}

Anonimous $^{1}$ (2013). Benefits of Water in Life. Retieved from http://www.kamusilmiah.com/tag/airbersih/

Anonimous ${ }^{2}$ (2015). Retrieved from https://id.wikipedia.org/wiki/Daftar ho tel di Kalimantan Selatan\#Banjarma

Anonimous ${ }^{\frac{\sin /}{3}}$ (2014). Banjarmasin in Figures 2014. Regional Development Planning Agency of Banjarmasin, South Kalimantan.

Anonimous $^{4}$ (1996). Clean Water Planning Criteria. Directorate General of Cipta Karya. Jakarta.

Ariyatno, D. (2007). An Analysis of Clean Water Demand and Supply at IPA (Water Processing Installation) Sumur Dalam Banjarsari PDAM Surakarta towards Total Customers. Thesis/Final Assignment of D-III Program of Civil Engineering. University of Sebelas Maret. Surakarta.

Linsey, K.R. (1996). Water Resource Engineering. Erlangga. Bandung.

Raju (1995). Water Supply and Wastewater Engineering. Tata McGraw-Hill Publishing Company Limited. New Delhi.

Sosrodarsono, S. \& Takeda, K. (1999). Hidrology for Irrigation. Pradnya Paramita. Jakarta.

Triatmodjo, B. (2006). Applied Hidrology. Beta Offset. Yogyakarta.

Wadsworth, Jr. \& Harrison, M. (1998). Handbook Of Statistical Methods For Engineers And Scientists. McGrawHill. New York.

Yasa, K. R. (2012). Environmental Quality standards. Retrieved from http://ruditayasa.blogspot.com/2012/0 9/baku-mutu-lingkungan.html?m=0 